\title{
Group decision making in nest-site selection by honey bees
}

\author{
Thomas D. SEELEY ${ }^{a *}$, P. Kirk VISSCHER ${ }^{b}$ \\ ${ }^{a}$ Department of Neurobiology and Behavior, Cornell University, Ithaca, NY 14853, USA \\ ${ }^{b}$ Department of Entomology, University of California, Riverside, CA 92521, USA
}

(Received 8 August 2003; revised 5 November 2003; accepted 30 November 2003)

\begin{abstract}
In recent years, renewed attention has been paid to the mechanisms of group decision making that underlie the nest-site selection process in honey bees. We review the results of these new investigations by discussing how the recent work builds on the earlier descriptive studies of this decision-making process, how the decision-making abilities of swarms have been tested, and how the mechanisms of this decisionmaking process have been experimentally analyzed. We conclude by discussing how the scouts in a swarm sense when their group decision making is coming to an end and so should begin stimulating their quiescent swarm-mates to prepare for the flight to their new home.
\end{abstract}

Apis mellifera / group decision making / honey bee / nest-site selection / swarming / waggle dance

\section{INTRODUCTION}

For centuries, beekeepers have known that after a swarm leaves its hive and coalesces into a cluster hanging from a tree branch, it searches for a home and, if left alone, eventually departs for a new abode. Because humans usually have hived the bivouacked swarms they have found, and so have cut short the bees' process of nest-site selection, it is not surprising that this process long remained a deep mystery. This situation changed in the 1950's when Martin Lindauer (1951, 1953, 1955) published his classic studies of house hunting by honey bees. Lindauer discovered that the bees seen performing waggle dances on the surface of a swarm cluster are scouts advertising potential nest sites, not foragers announcing rich food sources. He then took advantage of Karl von Frisch's recent success in deciphering the waggle dance communication system (von Frisch, 1946) to eavesdrop on the "deliberations" conducted by a swarm's scouts as they consider a dozen or more possi- ble dwelling places and ultimately reach agreement on one of them.

The next phase in the analysis of the nestsite selection process of honey bees came in the 1970's when various investigators turned their attention to the actions of scout bees at possible nest sites rather than the activities of these bees at the swarm cluster. Numerous studies were conducted to address the question of how scouts judge the quality of a potential nest site (reviewed by Seeley, 1985; Witherell, 1985). For the races of Apis mellifera L. native to Europe, it was learned that an attractive nest site has a cavity volume greater than 10 liters and an entrance hole smaller than $30 \mathrm{~cm}^{2}$, perched several meters off the ground, facing south, and located at the floor of the cavity. Neither cavity shape nor entrance shape is important. When inspecting a site, a scout invests much time in walking the inner surfaces of the cavity and her perception of cavity volume is linked somehow to how much walking she must do to circumnavigate a cavity (Seeley, 1977; Franks and Dornhaus, 2003).

\footnotetext{
* Corresponding author: tds5@cornell.edu
} 
This research on the nest-site preferences of bees set the stage for the development of effective bait hives (Witherell, 1985; Schmidt and Thoenes, 1987, 1990), which have proven valuable in various settings, including the monitoring and control of swarms of Africanized honey bees in the southwestern US (Schmidt, 1990).

Over the last few years, renewed attention has been paid to the mechanisms of group decision making in honey bee swarms, essentially taking up where Lindauer left off in the 1950's. Ever since Lindauer published his findings, there has been much speculation about the mechanisms of this decision-making process (Wilson, 1971; Griffin, 1981, 2001; Markl, 1985) and this has made clear the need for further analytic work. Moreover, since Lindauer's time, there has been a tremendous growth in interest in how animal groups function as adaptive units in general (Bourke and Franks, 1995; Seeley, 1995; Sober and Wilson, 1998) and as decision makers in particular (Franks et al., 2002; Conradt and Roper, 2003). A swarm of honey bees choosing its future home is one of the most impressive examples known of an animal group functioning as an adaptive decision maker. In this paper, we review what has been learned lately about the mechanisms of group decision making by honey bee swarms.

Before delving into these mechanisms, we wish to draw attention to three requirements that a swarm of bees must fulfill to succeed in the demanding task of choosing a home. First, it must achieve an accurate decision. A colony's success depends critically on its occupying a cavity that is sufficiently roomy to hold the combs the colony will need for rearing its brood and storing its honey. At the same time, the cavity must be sufficiently tight to provide good protection from predators, robbers, and harsh weather. Second, it must achieve a speedy decision. Every additional hour that a swarm spends as an exposed cluster, hanging from a tree branch, lowers its energy reserves and raises its chances of being soaked by rain. And third, it must achieve a unified decision. A split decision would lead to swarm fragmentation, which would be disastrous in most cases given that a swarm usually has just one queen and so can establish just one fully functioning colony. Thus the central question that we face is this: how do the bees in a honey bee swarm work together to produce an accurate, speedy, and unified choice of a home?

\section{RENEWING THE ANALYSIS}

Since Lindauer's work in the 1950's, it has been clear that only a small minority of the bees in a swarm cluster - the scout bees - are actively involved in the decision-making process. The vast majority of a swarm's members remain quiescent until a decision has been made and it is time to fly to the chosen site. It has also been clear that the scout bees search the surrounding environment for suitable nest sites, advertise their finds by performing waggle dances, and eventually come to an agreement on one of these sites. What was not clear until recently is how exactly the scout bees behave to produce this agreement. As a first step toward solving this puzzle, we repeated Lindauer's observations of the scout bees' dances and thus their deliberations, but using video equipment to get a more complete picture of the scouts' dancing than was possible in the 1950's (Camazine et al., 1999; Seeley and Buhrman, 1999). Having only pencil and paper for recording the scout bees' behavior, Lindauer was greatly limited in the amount of dance information he could record. He settled on recording only the first dance performed by each dancing bee; a paint mark applied to each dancer as she performed her first dance enabled him to distinguish novice dancers (unmarked) from repeat dancers (marked). Working nearly 50 years later and blessed with video technology, we were able to record, playback, and analyze every dance performed on a swarm. Moreover, by working with small swarms of about 4000 bees, and labeling individuals so that they could be identified, we were able to attribute each dance to a particular scout bee and so were able to determine the dance history, and other behaviors, of every bee that contributed to a swarm's decision making.

Figure 1 shows one of the complete dance records of a swarm's decision making. The pattern resembles closely what Lindauer reported based on his first-dance-only records. The entire decision-making process required about 16 hours of dance activity by the scouts, 


\section{Swarm 3}

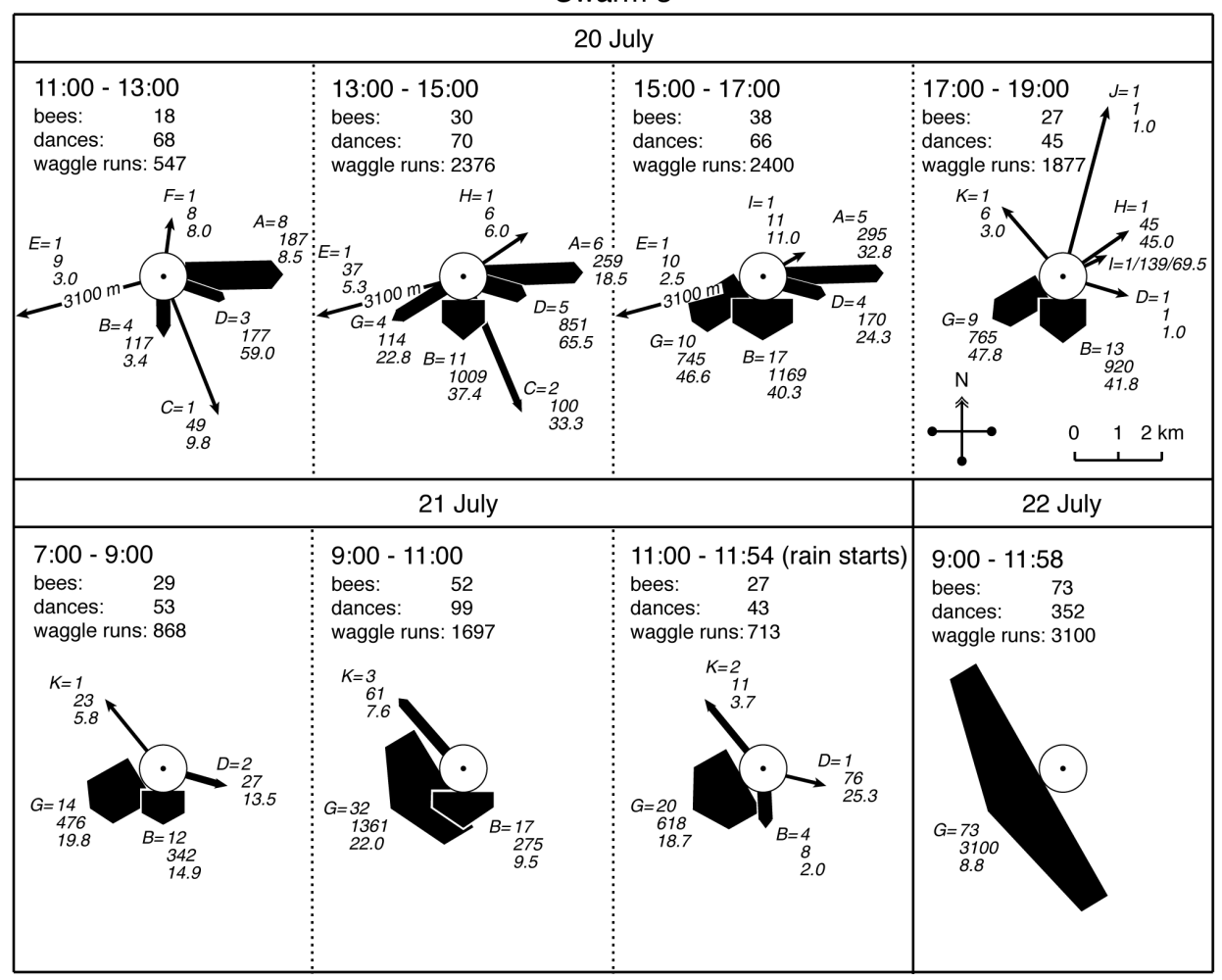

Figure 1. History of a swarm's decision-making process from the time that the first potential nest site was advertised on the swarm (shortly after 11:00 hours on July 20,1997) to when it lifted off to fly to its new home (at 11:58 hours on July 22, 1997). The circle within each of the panels represents the location of the swarm; each arrow pointing out from the circle indicates the distance and direction of a potential nest site; the width of each arrow denotes the number of different bees that danced for the site in the time period shown. The set of numbers at the tip of each arrow denotes three things: top the number of bees that danced for the site, middle the number of waggle runs performed for the site, bottom the mean number of waggle runs per dance for the site. The numbers after "bees", "dances", and "waggle runs" within each panel denote the total number of each (summed over all the potential nest sites) for the time period shown. (From Behav. Ecol. Sociobiol. 45, Seeley and Buhrman, 1999, (C) Springer-Verlag.)

spread over 3 days (a period of rain starting around noon on day 2 extended the process into day 3). We see that during the first half of the decision-making process, the scout bees reported all 11 of the potential nest sites that they would consider. We can also see that during the first half of the process no one site dominated the dancing; during the second half, however, one of the sites gradually began to be advertised much more than the others. Indeed, during the last few hours of the decision making, the site that had emerged as the frontrunner (site $\mathrm{G}$ ) became the object of all the dances - more than 3000 waggle runs - performed on the swarm. By the end, there was unanimity among the dancing bees.

This initial work confirmed many of the features of the swarm bees' decision-making process that had been previously reported by Lindauer based on his partial records of the dancing on swarms. These features include: (1) the scout bees locate potential nest sites in all directions and at distances of up to several kilometers from the swarm; (2) initially, the scout bees advertise a dozen or more potential nest sites but eventually they advertise just one site; (3) within an hour or so of the appearance of unanimity among the dancers, the swarm 
lifts off; (4) there is a crescendo of dancing just before liftoff; and (5) the chosen site is not necessarily the one that is first advertised on the swarm. Furthermore, the analysis of the dancing records of individual scout bees confirmed something else that Lindauer had suspected, which is that there is much turnover in the dancing bees over the course of a decisionmaking process. Most bees that dance for a site cease doing so after a few hours, letting the next "generation" of dancers carry on the deliberations. Thus it became clear that a swarm's choice of a future home is broadly distributed among the scout bees, and that this leaderless process of group decision-making consists of a friendly competition among the different groups of dancers representing the different potential nest sites. The groups compete for additional dancers. Sooner or later, one group of dancers grows numerous and ultimately excludes its competitors. The site whose dancers prevail in this winners-take-all contest becomes the swarm's new home.

\section{TESTING A SWARM'S DECISION-MAKING ABILITY}

Watching the dancing bees on a swarm build a consensus for a nest site naturally raises the following question: is the site that wins in the competition for dancers the best of the sites that the scout bees have found? The results of a recent study (Seeley and Buhrman, 2001) indicate that swarms are indeed generally successful in employing the best-of-N decision rule: sample some number $(\mathrm{N})$ of alternatives and then select the best one. In this study, five swarms of bees were transported one at a time to a windswept, brush-covered island along the coast of Maine, which had few natural nest sites. There each swarm was presented with an array of five nest boxes; four provided a mediocre but acceptable home site - a 15-liter cavity - and one offered an excellent home site - a 40-liter cavity. The record of each swarm's search for and choice among these five alternative nest sites is shown in Figure 2. We see that in each case the scout bees discovered one or more of the mediocre sites well before they located the excellent site, sometimes several hours in advance, and that they recruited other bees to the mediocre site. However, we also see in each case, except trial 4 , that as soon as the excellent site was discovered the bees recruited very strongly to this site and that within a few hours the number of scout bees at the excellent site greatly exceeded the number at any of the mediocre sites. Ultimately, each swarm, except the fourth, lifted off and flew toward the excellent site. Thus, in four out of five trials, swarms selected the best site, an outcome that is extremely unlikely $(P=$ 0.0064 ) to have occurred simply by chance.

\section{ANALYZING THE DECISION-MAKING PROCESS}

As mentioned already, a key requirement of the decision-making process of honey bee swarms is that it produces a unified decision, for ultimately a swarm will occupy just one nest site. It is, therefore, not surprising that before a swarm lifts off to fly to its chosen site, almost always the dancers on the swarm have reached an agreement such that all of their dances indicate a single location. (Below we will discuss what happens when a swarm mistakenly lifts off before the dancers have reached an agreement, and what these mistakes reveal about how the bees control their preparations for liftoff.) Only recently, however, have we gained a clear picture of how the scouts behave so that eventually all of their dances are performed for one of the several sites under consideration, usually the best one.

How do the scouts build a consensus for the best site? The descriptive studies discussed above indicate that the essence of the nest-site selection process is a friendly competition among the scouts "committed" to the various potential nest sites. Each coalition of scouts committed to a particular site competes with the other coalitions for additional members drawn from the pool of uncommitted scouts. For the basic situation of a choice between two sites, the swarm bees' decision-making process can be conceptualized with the simple pair of equations that were put forth by Winsor (1934) (cited by Hutchinson, 1978) early in the history of ecological competition theory:

$$
\begin{aligned}
& \mathrm{dN}_{1} / \mathrm{dt}=\mathrm{r}_{1} \mathrm{~N}_{1} \mathrm{U}-\mathrm{a}_{1} \mathrm{~N}_{1} \\
& \mathrm{dN}_{2} / \mathrm{dt}=\mathrm{r}_{2} \mathrm{~N}_{2} \mathrm{U}-\mathrm{a}_{2} \mathrm{~N}_{2}
\end{aligned}
$$


Nestbox $1 \quad$ Nestbox 2

Nestbox 3

Nestbox $4 \quad$ Nestbox 5

Trial 1: 16 July 1998 (swarm 98-3)
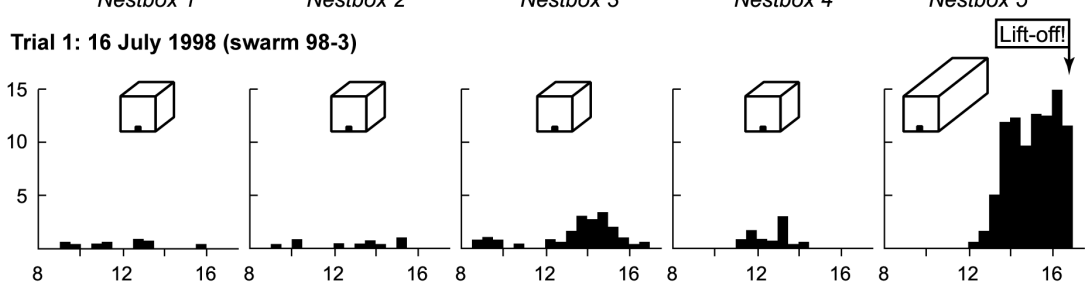

Trial 2: 21 July 1998 (swarm 98-4)

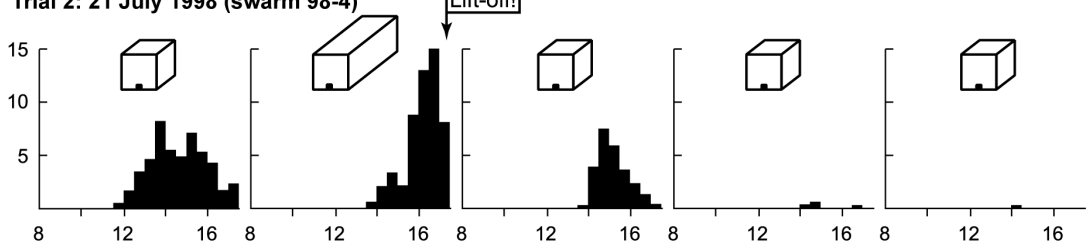

Trial 3: 3 \& 4 August 1998 (swarm 98-5)
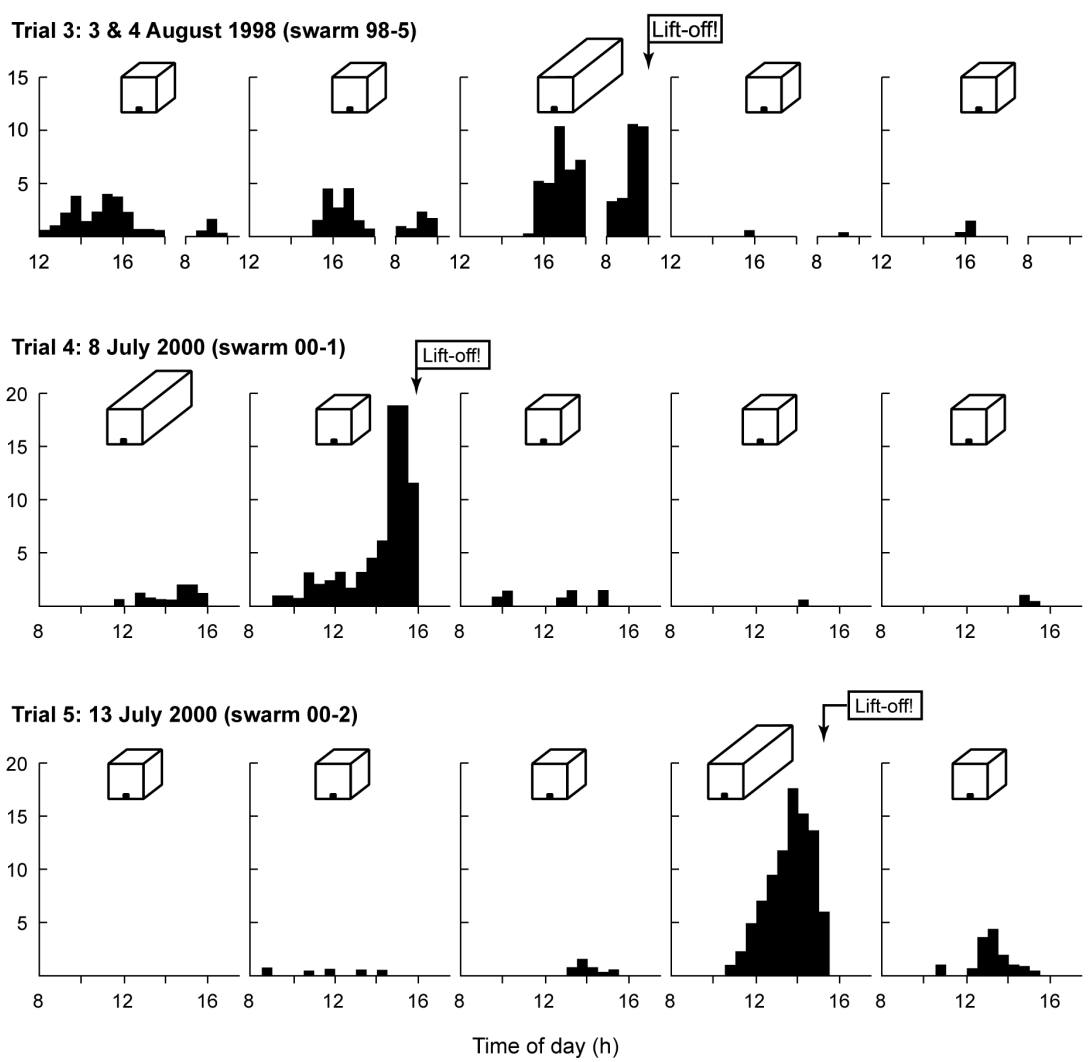

Figure 2. Results of five trials of a test of the ability of swarms to select the best of available nest sites. Five nest boxes were arranged in a fan-shaped array with each box 230-250 m from the swarm. One nest box was an excellent nest site (40-L cavity) while the other four were only mediocre sites (15-L cavities). A count of the number of scout bees visible at each nest box was made every $30 \mathrm{~min}$. In each trial, one or more of the mediocre sites was discovered 1-14 hours before the excellent site. Nevertheless, by the end of each trial, except the fourth, the swarm chose the 40-L site. Thus we see that most of these swarms were accurate decision makers. (From Behav. Ecol. Sociobiol. 49, Seeley and Buhrman, 2001, ( Springer-Verlag.) 
$\mathrm{N}_{\mathrm{i}}$ is the number of scouts committed to site $\mathrm{i}$, $\mathrm{U}$ is the number of uncommitted scouts (the resource being competed for), $r_{i}$ is the recruitment ("birth") rate per scout committed to site $\mathrm{i}$, and $\mathrm{a}_{\mathrm{i}}$ is the abandonment ("death") rate per scout committed to site i. Integrating and eliminating $U$ from the two equations yields

$$
\mathrm{N}_{1}^{\mathrm{r}_{2}} / \mathrm{N}_{2}^{\mathrm{r}_{1}}=\mathrm{Ce}^{\left(\mathrm{r}_{1} \mathrm{a}_{2}-\mathrm{r}_{2} \mathrm{a}_{1}\right) \mathrm{t}} .
$$

Thus if the scouts behave with a higher per capita rate of recruitment to site 1 than site 2 , and a higher per capita rate of abandonment of site 2 than site 1 , then the quantity $\left(r_{1} a_{2}-r_{2} a_{1}\right)$ has a positive value and the ratio on the left side of equation (3) is increasing. This implies the gradual elimination of the coalition of scouts committed to site 2 . In ecological theory, these equations are useful as perhaps the simplest expression of the principle of competitive exclusion. They are useful in the present context by showing how differences in per capita rates of recruitment to and abandonment of different potential nest sites are sufficient to produce a clear winner in the competition among coalitions of scout bees. In this model, the competition is for a single resource - uncommitted scout bees - and occurs purely by exploitation. In principle, the competition among coalitions could also involve interference, with scouts of a given coalition directly inhibiting the growth of the other coalitions, and this possibility will be considered below.

There is now solid evidence that scouts do adjust their behavior in relation to site quality so that the best site has both the highest per capita rate of recruitment $\left(r_{i}\right)$ and the lowest per capita rate of abandonment $\left(\mathrm{a}_{\mathrm{i}}\right)$. Lindauer (1955) stated that scouts reporting better sites perform longer and livelier dances (which should result in a higher per capita recruitment rate), but his evidence was only anecdotal. Seeley and Buhrman (2001) obtained experimental evidence in support of Lindauer's claim. Their approach was to present a swarm with both an excellent (40 L) nest box and a mediocre $(15 \mathrm{~L})$ nest box, and then to video record the scout bees' dances for the two nest boxes as they were performed side-by-side on the swarm. This experiment was performed with two swarms and in both cases they found that the dances for the excellent nest box were stronger than those for the mediocre nest box, there being on average 36 and 14 waggle runs per dance for the excellent and mediocre nest boxes, respectively. They also found that Lindauer was indeed correct when he stated that better sites elicit dances that are both longer and livelier than those elicited by poorer sites. Specifically, Seeley and Buhrman found that a scout bee tunes her dance strength by adjusting the number of waggle runs/dance, and that she adjusts the number of waggle runs/dance $(W)$ by changing both the duration $(D)$ and the rate $(R)$ of her waggle-run production (note that $W=D \times R$ ). Further analysis of the video recorded dances revealed that a dancing bee adjusts the rate of her waggle-run production by changing the mean duration of the return-phase portion of her dance circuits. Evidently, it was these differences in returnphase duration that gave Lindauer (1955) the impression that dances differ in liveliness.

The rate of recruitment by a dance-producing scout bee depends not only on how strongly she dances (number of waggle runs per dance), but also on how the dance-following scouts sample and respond to the various dances being performed on the surface of a swarm. The simplest possibility is that when a scout decides to follow a dance, she chooses a dancer at random and heeds her dance. If so, then the greater the per capita production of waggle runs for a site, the higher will be the per capita rate of recruitment to the site. Visscher and Camazine (1999) report evidence that scouts do indeed follow dances chosen at random. In a desert area, they provided a swarm with two nest boxes - one east and one west of the swarm - and they labeled each dancer for individual identification when she first danced for one of the nest boxes. They also videotaped all dancing and eventual dance following by the labeled bees throughout the swarm's decision-making process. When they examined how much time the labeled bees spent following dances for the east and west nest boxes, they found that they followed dances for each site in proportion to the total amount of dancing by other bees for the site, as shown in Figure 3. Evidently, when the labeled bees switched from dance producing to dance following (discussed further below), they showed no preference for either the dances advertising the site they had already 


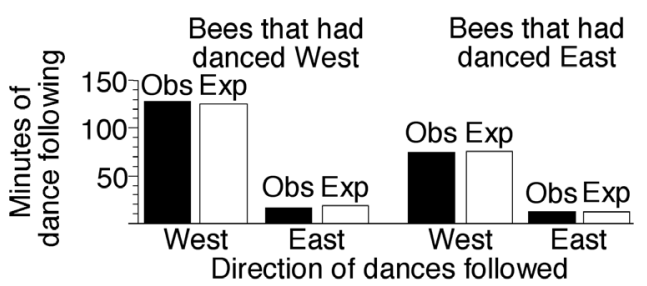

Figure 3. Scout bees that had originally danced for one of two available nest boxes (east or west) could later follow dances for each site. The expected amounts of dance following by each class of bees for each site (Exp) were calculated by parceling out total time each labeled dancer followed dances according to the distribution of dances available for her to follow. The actual distribution of dance following (Obs) closely matched this expectation, showing that scouts were not selective either for novel or familiar sites. (From Nature 397, Visscher and Camazine, 1999, (C) Nature Publishing Group.)

visited or the dances for the other site, and instead simply followed dances chosen at random.

So far we have considered only how scout bees committed to a site recruit other scouts to their site (i.e., what determines $r_{\mathrm{i}}$ ). Let us now consider instead how the scout bees committed to a site abandon this site, that is, how they stop dancing for and stop making visits to the site, and so terminate their commitment to the site (i.e., what determines $a_{i}$ ). This is one of the most curious features of the decision-making process of honey bee swarms. To conceptualize the matter, it is useful to recognize two classes of hypotheses for why a scout abandons a site: $\mathrm{H} 1$, an internal stimulus causes her to abandon a site; and $\mathrm{H} 2$, an external stimulus causes her to abandon a site. (Note: we know that scouts do not abandon their sites simply because they are dying. Seeley and Buhrman (1999) measured the mortality rate of scout bees in 3 swarms and found it to be low, with only $6 \%$ of the scouts dying over the course of the decision-making process.)

Hypothesis 1 is based upon the observation, made repeatedly in the descriptive studies (Lindauer, 1955; Camazine et al., 1999; Seeley and Buhrman, 1999) that scouts visiting nest sites rather quickly lose interest in their sites. With respect to dancing, for example, most scouts show a statistically significant tapering off over several hours in the number of waggle runs performed per dance. (Lindauer aptly called this a decline in Tanzlust.) Even scouts that start out visiting the ultimately chosen site, which presumably remains a high-quality site throughout the decision-making process, eventually cease performing dances for and stop making visits to this site. The fact that even scouts committed to the chosen site eventually abandon this site suggests strongly that the scouts' loss of interest is not the result of an external influence associated with being committed to an inferior site - for example, experiencing at the site a weak buildup of scouts or encountering at the swarm a vigorous dance for an alternative site - but is instead the result of an internally programmed process. One can argue that it may be highly adaptive for scouts to be programmed to eventually abandon their sites, because it could help prevent the decisionmaking process from becoming deadlocked due to unyielding scouts dancing for two or more sites.

Hypothesis 2 is based upon the observations made by Lindauer (1955) of 3 scout bees that stopped visiting one site at about the same time they started following dances for and began making visits to a second site. Lindauer (1971, 1975), Griffin (1992) and Gould and Gould (1994) have pointed out that these observations suggest that scouts will abandon one site only after they have followed dances for, inspected, and so gained interest in a superior site. "Bees that had visited a cavity of mediocre quality sometimes became followers of more enthusiastic dances than their own. Then some of them visited the better cavity they had learned about as followers of vigorous dances, returned, and danced appropriately with respect to the superior cavity they had now visited" (Griffin, 1992, p. 193). If bees decide to abandon a site only after they have learned about a superior site, it would be strong support for hypothesis 2 , because it would appear that information about a superior site (an external stimulus) is what causes a scout to abandon a site. However, the temporal relationship between abandonment of one site and recruitment to a second site was, until recently, unclear. It may be that scouts generally lose interest in one site even before they learn about a second site. If so, then this would be evidence against hypothesis 2 , because it 
would appear that the external stimulus of information about a superior site is not needed for a scout to abandon a site. It should be noted that the "before" scenario is supported by Lindauer's (1955) original observations. Each of the 3 scouts that he reported on stopped producing dances for (hence evidently was losing interest in) her first site well before she began following dances for her second site.

A recent study (Seeley, 2003) has addressed the critical issue of whether scouts that abandon a site do so only after they have followed dances for and made visits to a superior site (as predicted by hypothesis 2), or whether they will abandon a site even before they have experienced these external stimuli (as predicted by hypothesis 1). The behaviors of the first few (4-8) bees that performed dances in each of 6 swarms were monitored from the start of each bee's dancing to the end of her swarm's decision making. Because just a few scouts were monitored in each swarm, it was possible to record each time a focal scout left the swarm, returned to the swarm, produced a waggle dance, or followed a waggle dance. A total of 37 scout bees were observed, and 33 of them abandoned (ceased dancing for) the sites that they originally advertised with their dances. The critical finding was that only one of these 33 abandoners ceased dancing for her initial site after she began following dances for other sites. Most (32 out of 33) of these scouts lost interest in their sites without being influenced by the dances of other scouts, a fact which tends to contradict hypothesis 2 . Instead, it looks like these bees lost on their own (without external influence) their motivation to dance for their initial sites. A further piece of evidence that supports the internal stimulus hypothesis is the finding that the number of waggle runs produced by each bee for her initial site declined noticeably over her consecutive returns to the swarm and, as is shown in Figure 4, the pattern of decline in dancing per return to the swarm is strikingly linear. This linearity suggests that the pattern arises from an internal, neurophysiological process that automatically drives down a scout's motivation to dance for a site. This decline of dancing over repeated visits to a nest site appears to be a special feature of dancing in the context of house hunting; bees dancing in the context of nectar foraging do

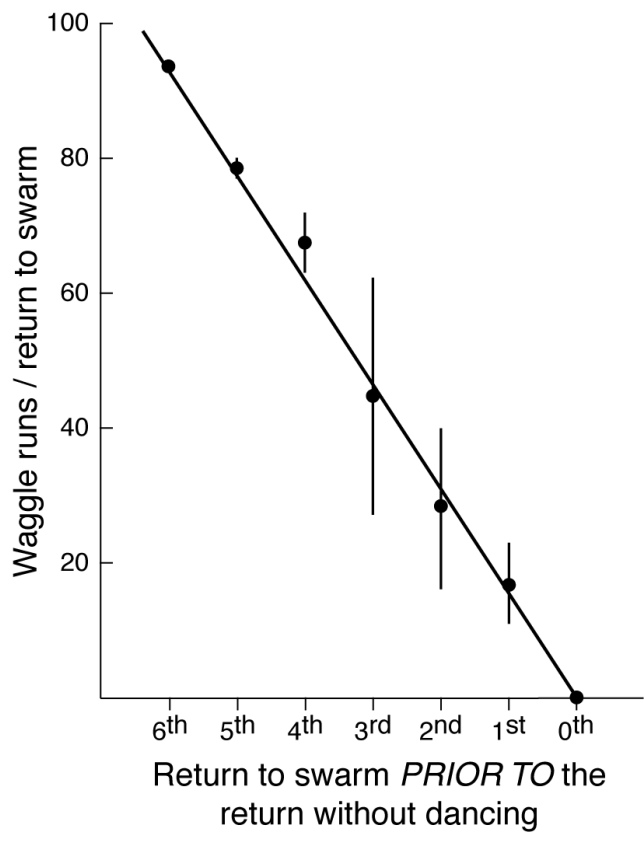

Figure 4. The number of waggle runs danced for a given site over consecutive returns to the swarm. Each of 37 scouts made 1-6 consecutive returns to the swarm with dancing and a final return without dancing ( $=0$ waggle runs/return). Some produced such a series for more than one site, so 51 series are included. The results show that a scout's tendency to dance for a site declines quickly and linearly over the course of her successive trips to the site. (From Behav. Ecol. Sociobiol. 53, Seeley, 2003, (C) Springer-Verlag.)

not show a decline in dancing over repeated visits to a food source (Seeley, 1994, Visscher, 2003).

Another important finding in the Seeley (2003) study is that the scout bees showed signs of adjusting their per capita rates of abandonment in relation to the quality of the site that each bee was advertising. Bees that performed dances for their swarm's chosen site (presumably a superior site) produced strong initial dances (mean number of waggle runs: 86.0) and continued producing dances over many (5-6) returns to the swarm. In comparison, bees that performed dances for one of their swarm's nonchosen sites (presumably sites inferior to the chosen one) produced weaker initial dances (mean number of waggle runs: 34.8) and danced over fewer (1-5) 
returns to the swarm. On average, therefore, nest-site scouts from a chosen site started stronger and lasted longer in advertising their sites than did scouts from a nonchosen site.

It appears that scout bees have a behavioral "rule" regarding the advertising of nest sites. The rule seems to be as follows: upon returning to the swarm for the first time after visiting a possible nest site, produce a dance whose strength (number of waggle runs) reflects the quality of the site, and upon making subsequent returns to the swarm, produce dances whose strength declines by about 15 waggle runs per return (see Fig. 4). By following this rule, nest-site scouts from superior sites will advertise their sites more strongly and will abandon their sites more slowly than will scouts from inferior sites. As a result, the better the site, the higher the per capita rate of recruitment of additional scouts $\left(r_{i}\right)$ and the lower the per capita rate of abandonment of existing scouts $\left(\mathrm{a}_{\mathrm{i}}\right)$. As mentioned above, such tuning of the per capita rates of recruitment and abandonment in relation to site quality is sufficient to explain how a consensus among the dancing bees is produced.

We end this section with a bit of speculation. Winsor's competition equations ( 1 and 2 ) refer only to competition by exploitation. Do the scouts of different coalitions compete entirely by mutual exploitation of the pool of uncommitted scout bees, or do they also compete by interference, that is by directly disrupting the growth of competing coalitions? The evidence presented above (the linear decay in dancing) suggests that scout bees are not stopping their dancing in response to external stimuli, but this may not be the whole story. Worker bees can produce a mechanical signal, the "stop signal", that is directed at waggle dancers and that causes them to stop dancing (Esch, 1964; Nieh, 1993; Kirchner, 1993). So far, the only context in which stop signals have been studied is in the hive, when a colony's nectar influx is excessive. In this situation, the nectar foragers have difficulty finding receiver bees to take their nectar, and these foragers produce stop signals (usually while tremble dancing) to inhibit waggle dancing and the recruitment of additional foragers (reviewed in Seeley, 1995, pp. 162-173). However, in the course of our studies, we have heard bees producing stop signals in swarms. (Stop signals are easily recognized because they are extremely brief, lasting just $0.1-0.2 \mathrm{~s}$, in contrast to all the other acoustical signals of worker bees which last much longer.) This raises the possibility that the scouts in one coalition could reduce the rate of recruitment of scouts in competing coalitions. And if scouts in different coalitions do interfere with one another, it may happen when a scout has switched her commitment from an inferior site to a superior site. A scout in this situation could contribute to the decision-making process by inhibiting dances representing her former, inferior site. It is known that some scouts do cross over from inferior to superior sites (Lindauer, 1955; Seeley and Buhrman, 1999; Camazine et al., 1999; Visscher and Camazine, 1999). However, no one has looked to see if crossover scouts produce stop signals directed at dancers advertising inferior sites. Visscher and Camazine (1999) have tested whether the removal of crossover scouts slows the decision-making process, as one would expect if interference by crossover scouts were important. They found no slowing. However, in performing their removal experiment, Visscher and Camazine used two identical nest boxes. Hence their crossover scouts did not experience a marked difference in quality between the two sites. It may be that direct experience with two sites that differ markedly in quality is necessary to induce a scout that has switched sites to inhibit dances for the inferior site. Clearly, the question of whether the decision-making process of honey bee swarms involves mechanisms of direct inhibition among the coalitions of dancers remains a subject for future investigation.

\section{EXPLORING HOW SWARMS PREPARE FOR LIFTOFF}

While the scouts are busy choosing a suitable nesting cavity, the other $95 \%$ of the bees in a swarm remain quiescent and conserve the swarm's energy reserve: the 30-40 $\mathrm{mg}$ of concentrated sugar solution carried inside each bee (Combs, 1972). As was shown by Heinrich (1981), the bees in the core of a swarm cluster maintain a $30-40{ }^{\circ} \mathrm{C}$ microclimate, by trapping the metabolic heat produced 
by the resting bees and by adjusting the cluster's porosity to control its rate of heat loss. Meanwhile, the outermost bees in a cluster maintain themselves above a relatively low set-point of $15{ }^{\circ} \mathrm{C}$, thus minimizing their energy expenditure for heat production but at the same time keeping their flight muscles warm enough to generate heat by shivering (Esch, 1988). In the final 10-30 min before liftoff, however, the temperature gradient in a swarm cluster becomes abolished such that the bees in the cluster's mantle become as warm as those at its core (Heinrich, 1981; Seeley and Tautz, 2001). Given that a worker bee needs a flight muscle temperature of at least $33-35^{\circ} \mathrm{C}$ for rapid flight (Esch, 1976; Heinrich, 1979), it is not surprising that such a striking warm-up phenomenon is observed. Using an infrared camera to measure the thoracic (flight muscle) temperatures of individual bees on the surface of a swarm cluster, Seeley et al. (2003) found that liftoff begins just a few seconds after all the surface-layer bees in a swarm cluster have their flight muscles warmed to at least $35{ }^{\circ} \mathrm{C}$. Swarm liftoff is a dazzling display of coordinated group behavior. All the bees in the swarm cluster launch into flight in about $60 \mathrm{~s}$, form a cloud of swirling bees, and begin moving off together, with the scouts somehow guiding all the others to their new dwelling place (Seeley et al., 1979, reviewed by Dyer, 2000).

We now understand some of the mechanisms whereby the bees in a swarm achieve such a beautifully coordinated liftoff. One of these is the buzz running (Schwirrlaufen) signal. During the final 10 or so minutes before liftoff, excited bees force their way through the quiet bees in the cluster, running about in a zig-zag pattern, butting into the other bees, meanwhile buzzing their wings (Lindauer, 1955; Esch, 1967). Many, perhaps most, of these buzz runners are scout bees and their actions appear to loosen up the cluster (Seeley et al., 1979). Martin (1963) demonstrated, with a split-hive experiment, that only bees contacted by buzz runners will join the mass exodus when a swarm initially leaves the parental hive. A second signal that helps activate the quiescent bees in a swarm cluster is the shaking signal (also called the vibration signal). To produce this signal, one bee grasps another and shakes this bee's body for 1-2 $\mathrm{s}$ at
16-18 Hz (see Fig. 1 in Seeley et al., 1998). There is strong evidence that the shaking signal acts as a modulatory signal that produces a general activation of worker bees in swarms (Schneider et al., 1998; Visscher et al., 1999; Lewis and Schneider, 2000; Donahoe et al., 2003; reviewed in Schneider and Lewis, 2004) and in hives (Schneider et al., 1986; Nieh, 1998; Seeley et al., 1998). However because the shaking signal does not occur solely or even principally in the last hour before liftoff, it seems that the shaking signal is not the signal that informs the relatively cool bees in a swarm that it is time to warm up for liftoff.

The principal warm-up signal is evidently the high-pitched piping signal that is produced during the last hour or so before departure (Lindauer, 1955; Seeley et al., 1979; Camazine et al., 1999). Seeley and Tautz (2001) investigated the origins and effects of this signal. They found that each piper is an excited bee that scrambles through the swarm cluster, pausing every second or so to press her thorax against another bee, pull her wings together over her abdomen, and activate her wing muscles to produce an audible vibration (though probably most of the vibrational energy is loaded into the contacted bee). Each pipe is a pulse of vibration which lasts $0.82 \pm$ $0.43 \mathrm{~s}$ and rises in fundamental frequency from $100-200 \mathrm{~Hz}$ to $200-250 \mathrm{~Hz}$. Many, if not all, of the pipers are scouts. The timecourse of worker piping matches that of swarm warming - both start at a low level about an hour before liftoff and both build to a climax at liftoff - which suggests that the scouts use this signal to stimulate their swarm mates to warm up. The results of an exclusion experiment also support this view of the function of worker piping. When pipers were excluded from a subset of bees hanging in the cool, outermost layer of a swarm cluster, it was found that these bees did not warm up, unlike adjacent bees that were contacted by pipers. It should be noted that the form of worker piping that occurs in swarms ("wings-together piping") is distinct from the form of worker piping that has been observed in hives ("wingsapart piping") (Ohtani and Kamada, 1980; Pratt et al., 1996). The function of the wingsapart piping signal remains a challenging mystery. 


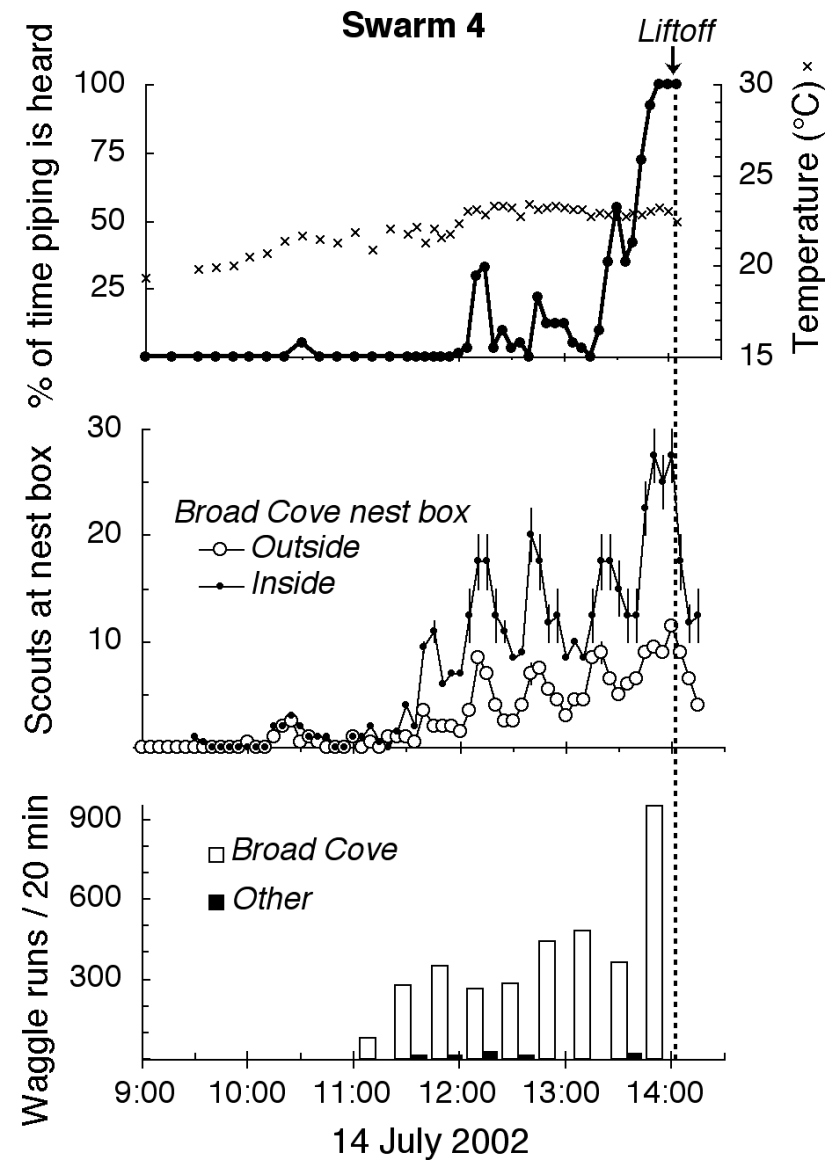

Figure 5. Results from monitoring a swarm as its scout bees chose between two potential nest sites (one a nest box and the other a site in an old house) and then began preparing for liftoff, which is indicated by the start of worker piping. At the swarm, we recorded the intensity of worker piping every 5 min and the number of waggle runs that were produced for each site in $20 \mathrm{~min}$ intervals before liftoff. At the potential nest sites, we recorded the number of scout bees outside and inside each site every $5 \mathrm{~min}$, except when one of the sites was an unidentified location in an old house. Note how every time the number of scouts inside the nest box rose well above 10 bees, piping began to be heard at the swarm, and how when the count fell to 10 or fewer bees, the piping decreased, usually stopping altogether. Note too that there was a consensus among the dancers throughout. (From Behav. Ecol. Sociobiol. 54, Seeley and Visscher, 2003, (C) Springer-Verlag.)

How do the scout bees sense when it is appropriate for them to begin producing the piping signals and so start stimulating their swarm-mates to prepare for the flight to their new home? Seeley and Visscher (2003) tested two hypotheses: "consensus sensing", the scouts noting when all the bees performing waggle dances are advertising just one site; and "quorum sensing", the scouts noting when one site is being visited by a sufficiently large number of scouts. To test these hypotheses, they monitored four swarms as they discov- ered, recruited to, and chose between two nest boxes and as their scouts started producing piping signals. They found that a consensus among the dancers was neither necessary nor sufficient for the start of worker piping, which indicates that the consensus-sensing hypothesis is false. They also found that a buildup of 10-15 or more bees at one of the nest boxes was consistently associated with the start of worker piping, which indicates that the quorum-sensing hypothesis may be true (Fig. 5). Recently, they tested experimentally the 
quorum-sensing hypothesis by seeing if they could delay the start of piping by slowing the buildup of scouts (i.e., quorum formation) at the chosen site but without disturbing anything else about the nest-site selection process (Seeley and Visscher, unpublished results). To do this, they presented swarms, one at a time, with five nest boxes together at one site, and they monitored the buildup of scouts at the nest boxes and the start of piping at the swarm. For comparison, they performed another trial with each swarm but with just one nest box at a site (different sites were used for the 1-nestbox and the 5-nest-box trials; also, the order of the 1- and 5-nest-box trials was reversed between consecutive swarms). They observed that the buildup of scout bees at a nest box was slower in the 5-nest-box trials (the recruits spread themselves among the nest boxes) than in the 1-nest-box trials (the recruits assembled at the single nest box), and that the onset of piping was much delayed in the 5-nest-box trials relative to the 1-nest-box trials. These results strongly support the quorum-sensing hypothesis, but leave open the question of how the scouts are sensing a quorum at the chosen site.

An intriguing question is why the scouts don't use consensus sensing and instead use quorum sensing. This question is particularly piquant given that a consensus, or at least a near consensus, among the dancers is required for a swarm to execute a successful move to a new home site. In three reported instances of a swarm lifting off when its dancers were strongly split between two sites (the Balcony and Moosach swarms of Lindauer, 1955, and swarm 3 of Seeley and Visscher, 2003), the airborne swarm divided, stalled in its move, and resettled. (Note: the occasional occurrence of liftoffs without consensus is further support for the quorum-sensing hypothesis.) Two of these swarms went on to achieve a dance consensus and a successful move, but one lost its queen when it split itself in midair and so experienced a complete failure. One possible reason for why the bees use quorum sensing is that it would be exceedingly difficult or costly for the scouts to sense a consensus among themselves as they perform dances on a swarm, for to do so would presumably require that each scout poll the dances by traveling over the swarm cluster, reading some sample of the dances, and keeping a tally of her readings. Another possible reason for using quorum sensing is that it provides an advantage in the speed of the decision making, by enabling the bees to begin preparations for liftoff as soon as enough of the scout bees, but not all of them, have approved of one of the potential nest sites. Presumably the reason that most liftoffs occur when there is a consensus among the dancers, even though a consensus is not the trigger for the start of liftoff preparations, is because there is the strong positive feedback process of vigorous dancing for the chosen site, which attracts more and more dancing for this superior site. It may be too that the quorum size has been tuned by natural selection to be sufficiently high to ensure that almost always a dance consensus is produced for a site shortly after a quorum of scouts is reached at this site.

\section{SWARM SMARTS}

In closing, we draw attention to two features of the group decision-making process that we have just discussed, features that contribute importantly to a swarm's success in choosing a new home. Let us not forget that each of these successes is a remarkable achievement. For while it is true that a swarm's decision making is simplified by having a clear and stable problem (i.e., find a single, suitable nest site), it is also complicated by the realities that the information used in this decision making is incomplete (at least early on), sometimes inaccurate (as when a scout dances weakly for a high-quality site; see Swarm 4 in Fig. 2), and steadily changing. Such informational messiness makes it difficult to apply the classical and powerful approach to decision making - identify alternatives, evaluate these options, and choose the one with the highest value - but swarms manage to do so. What are their secrets of success?

One is the use of dozens, if not hundreds, of scout bees that independently, widely, and simultaneously explore for potential nest sites. These scouts bring back to the swarm cluster heterogeneous information - knowledge of superb, mediocre, and even lousy sites - which is then shared with the other scouts by means of waggle dances. The important thing is that 
all discoveries of acceptable nest sites are freely reported; no scout is stifled. Thus a swarm takes advantage of its collective nature to assemble rather quickly, often in just a few hours (see Fig. 1), a large set of alternatives from which to choose. The larger this set, the more likely it includes a first-rate site.

A second important feature of the bee's decision-making process becomes apparent when we consider how the scouts solve the problem of finding the best of this large set of alternatives. At most, any individual has direct experience with only a few of these sites, but the decision-making process must compare all the sites. We have described already how the solution to this problem arises through a process of friendly competition among the scouts, with the various coalitions of scouts committed to different sites vying to attract uncommitted scouts. We have explained how the members of each coalition attract additional members by performing waggle dances that are graded in strength in relation to site quality, so that the higher the site quality, the stronger the dance, and the greater the stream of newcomers to it. Furthermore, the apparently endogenously programmed extinction of Tanzlust helps sharpen the differences in recruitment. But what we have not yet pointed out is that the bees have an important check on the positive feedback that will occur as dancers beget more dancers: a dance follower does not blindly imitate the dancer that she has followed. Instead, she leaves the swarm cluster, examines the advertised site, and only if she too judges that it is a worthy site does she produce a dance for it. In this way the population of scouts avoids possible runaway feedback in dancing for a poor site that happens to be discovered quickly. The procedure of inspecting a site before advertising it also provides the basis for the scouts deciding when the decision-making process has progressed sufficiently far for them to shift to stimulating swarm liftoff.

These considerations illustrate how the story of house hunting by honey bees contains valuable lessons about effective decision making by groups. There is no need for any individual to possess a global view of the alternatives, nor for any mechanism to tally and compare "votes" for them. The "smarts" of a swarm derives from a combination of many individuals working in parallel, each one making sophisticated assessments of nest-site properties, and a group process of feedback in recruitment, modulated by these quality assessments and amplified by the house-hunting-specific decay of Tanzlust. Together, these lead a swarm to an accurate, speedy, and unified decision.

\section{ACKNOWLEDGMENTS}

We are grateful to the National Science Foundation, the Alexander von Humboldt Foundation, the National Geographic Society, and the University of California-Riverside Academic Senate. Their financial support made possible many of the studies discussed in this article.

Résumé - Prise collective de décision dans le choix du site de nidification chez l'Abeille domestique. Une attention renouvelée a récemment été portée aux mécanismes de prise de décision collective chez les essaims d'abeilles domestiques (Apis mellifera L.) en se basant sur les études faites par Lindauer dans les années 50. Nous passons en revue les connaissances récentes sur la fonction d'un essaim dans la prise de décision.

Une première étape dans l'étude renouvelée du processus de choix du site de nidification a été de faire une description complète, à l'aide d'enregistrements vidéo, des danses des éclaireuses, et donc de leurs délibérations. Ceci a confirmé les traits fondamentaux du processus de prise de décision: les éclaireuses cherchent partout des sites potentiels de nidification, elles recrutent d'abord par les danses frétillantes pour de nombreux sites, puis ne recrutent éventuellement que pour un seul site et, peu après l'apparition d'un consensus parmi les danseuses, l'essaim s'envole vers le site choisi. Ce travail a aussi montré le taux élevé de renouvellement des danseuses au cours de la prise de décision de l'essaim. Les nouvelles études descriptives ont généralement confirmé que le choix d'un domicile par l'essaim consiste en une compétition amicale pour gagner de nouvelles danseuses entre groupes de danseuses représentant les divers sites potentiels. Un test a été réalisé sur la précision de la prise de décision par les essaims. Il a montré que les essaims réussissent généralement à présenter un certain nombre $\mathrm{N}$ d'alternatives et choisissent ensuite la meilleure (i.e. ils utilisent la règle de décision « le meilleur de $\mathrm{N} »)$.

De nombreux travaux ont cherché à comprendre comment les éclaireuses se comportent pour produire finalement une danse consensuelle pour le meilleur site de nidification. En principe cela se produit si les éclaireuses agissent de façon à ce que le meilleur site ait le plus fort taux de recrutement et 
le plus faible taux d'abandon par tête. On sait maintenant que les éclaireuses qui produisent la danse règlent la force de leur danse frétillante ( = nombre de trajets frétillants par danse) selon la qualité du site et que celles qui suivent la danse choisissent au hasard la danse à suivre. Le taux de recrutement par tête est une fonction positive de la qualité du site de nidification. On a aussi maintenant la preuve que les éclaireuses ajustent le taux d'abandon par tête en fonction de la qualité du site. Bien que les éclaireuses puissent éventuellement abandonner un site (cesser de danser pour lui), meilleur est le site, plus longtemps l'éclaireuse dansera pour lui.

Peu avant qu'un essaim s'envole pour son nouveau domicile, les abeilles échauffent leurs muscles de vol jusqu'à atteindre au moins $35^{\circ} \mathrm{C}$. Les éclaireuses produisent un chant en rassemblant leurs ailes pour inciter leurs consoeurs au repos à s'échauffer pour l'envol. Les éclaireuses décident curieusement du moment où elles se mettent à chanter lorsqu'elles sentent la formation d'un quorum d'éclaireuses pour le site choisi et non pas un consensus dans la danse sur la grappe de l'essaim. Ce sentiment de quorum peut servir à accélérer la prise de décision de l'essaim.

\section{Apis mellifera / décision collective / choix / site de nidification / essaimage / danse frétillante}

Zusammenfassung - Gruppenentscheidung bei der Nestsuche der Honigbienen. In den letzten Jahren wurde die Aufmerksamkeit erneut auf den Mechanismus der Gruppenentscheidung bei Schwärmen der Honigbienen gerichtet, die auf den Untersuchungen von Lindauer in den 1950er Jahren basieren. Wir geben eine Übersicht über neuere Erkenntnisse über die Funktion eines Schwarms bei der Fassung von Entscheidungen.

Ein erster Schritt bei der erneuten Untersuchung über den Entscheidungsprozess während der Suche nach einer geeigneten Nisthöhle bestand aus Video Aufnahmen, die eine vollständige Beschreibung der Tänze aller Kundschafterbienen und damit von ihren Beurteilungen ermöglichte. Hierbei bestätigten sich die wichtigsten Grundzüge des Entscheidungsprozesses: Kundschafter suchen überall nach Nistmöglichkeiten, anfangs werben sie für viele Nistgelegenheiten mit Schwänzeltänzen, aber allmählich werben sie nur noch für einen Nistplatz und kurz nach der Einigung der Tänzer fliegt der Schwarm zur erwählten Nisthöhle. Diese Filme dokumentieren auch eine hohe Zahl von Umgruppierungen der Tänzer während des Entscheidungsprozesses des Schwarms. Insgesamt haben die neuen Beobachtungen bestätigt, dass die Wahl des Schwarmes für eine neue Nisthöhle aus einer friedlichen Konkurrenz bei der Anwerbung von Tänzern zwischen den verschiedenen Gruppen ist, die Nistmöglichkeiten vorstellen.

Es wurde ein Test über die Genauigkeit der Entscheidungsfindung im Schwarm durchgeführt.
Dabei zeigte sich, dass Schwärme im allgemeinen erfolgreich eine Anzahl (N) von alternativen Nistmöglichkeiten aufzeigen und dann den besten auswählen (i.e., Anwendung der "besten-von-N" Entscheidungsregel).

Viele Arbeiten konzentrierten sich auf eine Aufklärung des Verhaltens der Kundschafter, das zum Schluss zu einem einheitlichen Tanz für die beste Nistgelegenheit führt. Im Prinzip geschieht das, wenn es den Kundschaftern gelingt, die meisten Einzelbienen (pro Kopf) zu rekrutieren und gleichzeitig den geringsten Verlust $\mathrm{zu}$ haben. Inzwischen ist bekannt, dass die tanzenden Kundschafterinnen die Stärke ihres Schwänzeltanzes mit der Qualität des Nistplatzes abstimmen (=Anzahl von Schwänzelläufen pro Tanz), und dass die der Tänzerin nachfolgenden Kundschafterinnen zufällig einem Tanz folgen. Eine pro Kopf Rate von Neulingen hat eine einigende Wirkung und zeigt eine positive Reaktion auf der Qualität des Nistplatzes an. Auch gibt es jetzt Befunde, dass Kundschafterinnen die pro Kopf Rate von den Tanz verlassenden Bienen in Bezug zur Qualität setzen. Obwohl alle Kundschafterinnen nach und nach aufhören (nicht mehr für den Platz tanzen), tanzen sie doch länger, je besser der Platz ist.

Kurz bevor der Schwarm startet und zu seinem neuen Heim fliegt, wärmen die Bienen ihre Flugmuskeln auf mindestens $35^{\circ} \mathrm{C}$ auf. Die Kundschafterinnen erzeugen ein Piping Signal durch Zusammenlegung ihrer Flügel, das zur Stimulierung ihrer ruhig gebliebenen Schwarmgenossinnen zur Aufwärmung für den Abflug führt. Seltsamerweise entscheiden die Kundschafterinnen über den Beginn des Piping Signals. Sie erkennen die Entscheidung einer ausreichenden Zahl an Kundschafterinnen für einen Platz, sie messen nicht die Einigung im Tanz auf der Traube. Dieses Gefühl für ein Quorum mag dazu dienen, die Entscheidungsfindung $\mathrm{zu}$ beschleunigen.

Apis mellifera / Findung einer Gruppenentscheidung / Wahl des Nistplatzes / Schwärmen / Schwänzeltanz

\section{REFERENCES}

Bourke A., Franks N.R. (1995) Social evolution in ants, Princeton University Press, Princeton, New Jersey.

Camazine S., Visscher P.K., Finley J., Vetter R.S. (1999) House-hunting by honey bee swarms: collective decisions and individual behaviors, Insectes Soc. 46, 348-360.

Combs G.F. (1972) The engorgement of swarming worker honeybees, J. Apic. Res. 11, 121-128.

Conradt L., Roper T.J. (2003) Group decision-making in animals, Nature 421, 155-158.

Donahoe K., Lewis L.A., Schneider S.S. (2003) The role of the vibration signal in the house-hunting 
process of honey bee (Apis mellifera) swarms, Behav. Ecol. Sociobiol. 54, 593-600.

Dyer F.C. (2000) Group movement and individual cognition: lessons from social insects, in: Boinski S., Garber P.A. (Eds.), On the move: how and why animals travel in groups, University of Chicago Press, Chicago, pp. 127-164.

Esch H. (1964) Beiträge zum Problem der Entfernungsweisung in den Schwänzeltänzen der Honigbiene, Z. Vergl. Physiol. 48, 534-546.

Esch H. (1967) The sounds produced by swarming honey bees, Z. Vergl. Physiol. 56, 408-411.

Esch H. (1976) Body temperature and flight performance of honey bees in a servomechanically controlled wind tunnel, J. Comp. Physiol. 109, 264277.

Esch H. (1988) The effects of temperature on flight muscle potentials in honeybees and cuculiinid winter moths, J. Exp. Biol. 135, 109-117.

Franks N.R., Dornhaus A. (2003) How might individual honeybees measure massive volumes, Proc. R. Soc. London B (Suppl.) 270, S181-S182.

Franks N.R., Pratt S.C., Mallon E.A.B., Britton N.F., Sumpter D.J.T. (2002) Information flow, opinion polling and collective intelligence in househunting social insects, Philos. Trans. R. Soc. London B 337, 1567-1583.

Frisch K. von (1946) Die Tänze der Bienen, Österr. Zool. Z. 1, 1-48.

Gould J.L., Gould C.G. (1994) The animal mind, Scientific American Library, New York.

Griffin D.R. (1981) The question of animal awareness, Rockefeller University Press, New York.

Griffin D.R. (1992) Animal minds, University of Chicago Press, Chicago.

Griffin D.R. (2001) Animal minds: beyond cognition to consciousness, University of Chicago Press, Chicago.

Heinrich B. (1979) Thermoregulation of African and European honeybees during foraging, attack, and hive exits and returns, J. Exp. Biol. 80, 217-229.

Heinrich B. (1981) The mechanisms and energetics of honeybee swarm temperature regulation, J. Exp. Biol. 91, 25-55.

Hutchinson G.E. (1978) An introduction to population ecology, Yale University Press, New Haven.

Kirchner W.H. (1993) Vibrational signals in the tremble dance of the honeybee, Apis mellifera, Behav. Ecol. Sociobiol. 33, 169-172.

Lewis L.A., Schneider S.S. (2000) The modulation of worker behavior by the vibration signal during house hunting in swarms of the honeybee, Apis mellifera, Behav. Ecol. Sociobiol. 48, 154-164.

Lindauer M. (1951) Bienentänze in der Schwarmtraube, Naturwissenschaften 38, 509-513.

Lindauer M. (1953) Bienentänze in der Schwarmtraube. II, Naturwissenschaften 40, 379-385.

Lindauer M. (1955) Schwarmbienen auf Wohnungssuche, Z. Vergl. Physiol. 37, 263-324.
Lindauer M. (1971) Communication among social bees, 2nd ed., Harvard University Press, Cambridge, Massachusetts.

Lindauer M. (1975) Verständigung im Bienenstaat, Fischer Verlag, Stuttgart.

Markl H. (1985) Manipulation, modulation, information, cognition: some riddles of communication, in: Hölldobler B., Lindauer M. (Eds.), Experimental behavioral ecology and sociobiology, Fischer Verlag, Stuttgart, pp. 163-194.

Martin P. (1963) Die Steuerung der Volksteilung beim Schwärmen der Bienen. Zugleich ein Beitrag zum Problem der Wanderschwärme, Insectes Soc. 10, 13-42.

Nieh J.C. (1993) The stop signal of honey bees: reconsidering its message, Behav. Ecol. Sociobiol. 33, 51-56.

Nieh J.C. (1998) The honey bee shaking signal: function and design of a modulatory communication signal, Behav. Ecol. Sociobiol. 42, 23-36.

Ohtani T., Kamada T. (1980) 'Worker piping': the piping sounds produced by laying and guarding worker honeybees, J. Apic. Res. 19, 154-163.

Pratt S.C., Kühnholz S., Seeley T.D., Weidenmuller A. (1996) Worker piping associated with foraging in undisturbed queenright colonies of honey bees, Apidologie 27, 13-20.

Schmidt J.O. (1990) Swarm traps: an example of research and technology transfer, Am. Bee J. 130, 333-334.

Schmidt J.O., Thoenes S.C. (1987) Swarm traps for survey and control of Africanized honey bees, Bull. Entomol. Soc. Am. 33, 155-158.

Schmidt J.O., Thoenes S.C. (1990) Honey bee (Hymenoptera: Apidae) preferences among artificial nest cavities, Ann. Entomol. Soc. Am. 83, 271-274.

Schneider S.S., Lewis L.A. (2004) The vibrational signal, modulatory communication and the organization of labor in honey bees, Apis mellifera, Apidologie 35, 117-131.

Schneider S.S., Stamps J.A., Gary N.E. (1986) The vibration dance of the honey bee. I. Communication regulating foraging on two time scales, Anim. Behav. 34, 377-385.

Schneider S.S., Visscher P.K., Camazine S. (1998) Vibration signal behavior of waggle-dancers in swarms of the honey bee, Apis mellifera (Hymenoptera: Apidae), Ethology 104, 963-972.

Seeley T.D. (1977) Measurement of nest cavity volume by the honeybee (Apis mellifera), Behav. Ecol. Sociobiol. 2, 201-227.

Seeley T.D. (1985) Honeybee ecology, Princeton University Press, Princeton, New Jersey.

Seeley T.D. (1994) Honey bee foragers as sensory units of their colonies, Behav. Ecol. Sociobiol. $34,51-62$.

Seeley T.D. (1995) The wisdom of the hive, Harvard University Press, Cambridge, Massachusetts.

Seeley T.D. (2003) Consensus building during nestsite selection in honey bee swarms: the expiration 
of dissent, Behav. Ecol. Sociobiol. 53, 417424.

Seeley T.D., Buhrman S.C. (1999) Group decision making in swarms of honey bees, Behav. Ecol. Sociobiol. 45, 19-31.

Seeley T.D., Buhrman S.C. (2001) Nest-site selection in honey bees: how well do swarms implement the 'best-of-N' decision rule? Behav. Ecol. Sociobiol. 49, 416-427.

Seeley T.D., Tautz J. (2001) Worker piping in honey bee swarms and its role in preparing for Liftoff, J. Comp. Physiol. A 187, 667-676.

Seeley T.D., Visscher P.K. (2003) Choosing a home: how the scouts in a honey bee swarm perceive the completion of their group decision making, Behav. Ecol. Sociobiol. 54, 511-520.

Seeley T.D., Morse R.A., Visscher P.K. (1979) The natural history of the flight of honey bee Swarms, Psyche 86, 103-113.

Seeley T.D., Weidenmüller A., Kühnholz S. (1998) The shaking signal of the honey bee informs workers to prepare for greater activity, Ethology $104,10-26$.
Seeley T.D., Kleinhenz M., Bujok B., Tautz J. (2003) Thorough warm-up before take-off in honey bee swarms, Naturwissenschaften 90, 256-260.

Sober E., Wilson D.S. (1998) Unto others, Harvard University Press, Cambridge, Massachusetts.

Visscher P.K. (2003) How self-organization evolves, Nature 421, 799-800.

Visscher P.K., Camazine S. (1999) Collective decisions and cognition in bees, Nature 397, 400.

Visscher P.K., Shepardson J., Camazine S. (1999) Vibration signal modulates the behavior of house-hunting honey bees (Apis mellifera), Ethology 105, 759-769.

Wilson E.O. (1971) The insect societies, Harvard University Press, Cambridge, Massachusetts.

Winsor C.P. (1934) Mathematical analysis of growth of mixed populations, Cold Spring Harbor Symp. Quant. Biol. 2, 181-187.

Witherell P.C. (1985) A review of the scientific literature relating to honey bee bait hives and swarm attractants, Am. Bee J. 125, 823829. 